УДК 619:577.12:612.122:636.2.082.455

(C) 2013

Семерунчик А. Д., аспірант*

Національний університет біоресурсів і природокористування України

\title{
ЗМІНИ ВМІСТУ ГЛЮКОЗИ В СИРОВАТЦІ КРОВІ КОРІВ УПРОДОВЖ ВАГІТНОСТІ ТА В ПІСЛЯРОДОВИЙ ПЕРІОД
}

\section{Рецензент - доктор біологічних наук Л. Г. Калачнюк}

\begin{abstract}
Біохімічні показники сироватки крові тварин, як показник стану обміну речовин в організмі, можуть слугувати маркерами порушення відтворювальної функиії у тварин. Наведено динаміку коливань рівня глюкози у сироватці крові в період вагітності та післяродовий період у корів різного віку. Встановлено підвищення рівня вмісту глюкози відносно верхньої фізіологічної межі в сироватці крові тільних корів, щуо обумовлено активуванням енертетичного обміну організму матері. Зниження глюкози в сироватиі крові в післяродовий період до фізіологічних меж вказує повернення тварини до не вагітного стану.
\end{abstract}

Ключові слова: тільність, нетелі, первістки, велика рогата худоба (ВРX), сироватка крові, глюкоза, гіперглікемія.

Постановка проблеми. Глюкоза в організмі тварини виконує функцію джерела енергії та $\epsilon$ субстратом для багатьох хімічних реакцій [6]. Вона основний субстрат енергетичного обміну. Понад половину енергії, що використовується здоровим організмом, утворюється за рахунок окиснення глюкози [2]. Глюкоза та іï похідні наявні в більшості органів і тканин. Концентрація глюкози в крові залежить від активності процесів глікогенезу, глікогенолізу, глюконеогенезу і гліколізу [3].

Характерні для періоду вагітності фізіологічні зміни супроводжуються відповідними змінами вмісту глюкози в крові [1]. За даними I. Мороза, кількість глюкози в крові збільшувалася влітку, коли тварини отримували зелену масу з достатньою кількістю легкозасвоюваних вуглеводів [4].

Мета досліджень: дослідити динаміку зміни глюкози в сироватці крові нетелей, первісток та корів 3-4-го отелу за тиждень до отелу; вплив даного фактору на перебіг родового процесу і на відтворювальну функцію корів.

Завдання досліджень: вивчити динаміку вмісту глюкози в сироватці крові тільних корів другої, третьої, четвертої тільності та нетелей, а також дослідити взаємозв'язок даного показника крові з відтворювальною здатністю корів.

Методика проведення досліджень. Дослідження проводили на великій рогатій худобі голштинської породи ПСП «Колос» м. Бородянка Київської області. За 5 днів до отелення 3 підхвостової вени піддослідних тварин відбирали кров, із якої шляхом центрифугування $(500 \mathrm{~g}$, 15-20 хв) одержували сироватку, в якій визначали вміст глюкози глюкозооксидазним методом i на автоматичному біохімічному аналізаторі «Вітрос 350».

Результати досліджень. У результаті дослідження сироватки крові тільних нетелей встановлено, що вміст глюкози в ній на першому місяці тільності підвищувався на $6 \%$ (див. табл.) порівняно з верхньою межею фізіологічної норми й залишався на цьому ж рівні до п'ятого місяця тільності.

\section{Динаміка вмісту глюкози в сироватці крові різних вікових груп у корів} упродовжс вагітності, ммоль/л

\begin{tabular}{|c|c|c|c|c|c|c|}
\hline \multirow{2}{*}{ Групи тварин } & \multicolumn{7}{|c|}{ Періоди досліджень } \\
\cline { 2 - 7 } & $\begin{array}{c}\text { 1 міс. } \\
\text { тільності }\end{array}$ & $\begin{array}{c}5 \text { міс. } \\
\text { тільності }\end{array}$ & $\begin{array}{c}7 \text { міс. } \\
\text { тільності }\end{array}$ & $\begin{array}{c}\text { 9 міс. } \\
\text { гільності }\end{array}$ & $\begin{array}{c}14 \text { днів } \\
\text { тільності } \\
\text { після родів }\end{array}$ \\
\hline Нетелі $(\mathrm{n}=8)$ & $3,5 \pm 0,12$ & $3,5 \pm 0,09$ & $4,03 \pm 0,04$ & $3,8 \pm 0,05$ & $3,4 \pm 0,12$ & $3,25 \pm 0,34$ \\
\hline Первістки $(\mathrm{n}=8)$ & $3,6 \pm 0,36$ & $3,6 \pm 0,13$ & $3,4 \pm 0,53$ & $3,5 \pm 0,19$ & $3,4 \pm 0,34$ & $3,03 \pm 0,6$ \\
\hline $\begin{array}{c}\text { Корови 3-4-ї } \\
\text { лактацій } \\
(\mathrm{n}=8)\end{array}$ & $3,3 \pm 0,44$ & $3,8 \pm 0,12$ & $3,3 \pm 0,04$ & $3,5 \pm 0,19$ & $3,8 \pm 0,49$ & $2,4 \pm 0,21$ \\
\hline
\end{tabular}

$\bar{*}$ *ауковий керівник - доктор біологічних наук, професор, член-кореспондент НААНУ В. А. Яблонський 
На сьомому місяці тільності рівень глюкози збільшувався на $22 \%$, порівняно 3 верхньою межею фізіологічної норми; на восьмому місяці тільності він дещо знижувався, але був на $15 \%$ вищим від верхньої межі фізіологічної норми. На дев'ятому місяці вагітності рівень вмісту глюкози в сироватці крові був вищим від верхньої межі фізіологічної норми лише на $3 \%$. Упродовж перших двох тижнів після родів рівень глюкози в сироватці крові корів знизився до фізіологічної межі й становив 3,25 $\pm 0,12$ ммоль/л.

У тільних первісток вміст глюкози в сироватці крові на першому місяці тільності був вищим порівняно з верхньою межею фізіологічної норми на $9 \%$ i залишався на цьому ж рівні до п’ятого місяця тільності; на сьомому місяці тільності він перевищував верхню межу фізіологічної норми на $3 \%$; на восьмому місяці тільності був вищим порівняно 3 верхньою межею фізіологічної норми на $6 \%$; дев'ятий місяць тільності характеризувався перевищенням вмісту глюкози в сироватці крові на 3 \%. У післяродовий період рівень глюкози в сироватці крові корів відповідав фізіологічним нормам i становив 3,03 $\pm 0,6$ ммоль/л. У тільних корів третьоїчетвертої лактацій вміст глюкози в сироватці крові на першому місяці вагітності був на рівні верхньої фізіологічної межі й становив 3,3 $\pm 0,44$ ммоль/л; на п’ятому місяці він підвищувався на $15 \%$ порівняно з верхньою фізіологічною нормою показника; на сьомому місяці вагітності знаходився на верхній фізіологічній межі; на восьмому місяці вагітності збільшувався на $6 \%$ порівняно 3 верхньою фізіологічною межею; на дев'ятому місяці вагітності вміст глюкози в сироватці крові збільшувався на $15 \%$ стосовно верхньої фізіологічної межі показника. Впродовж перших двох тижнів після родів рівень глюкози в сироватці крові корів 3-4-ї лак-

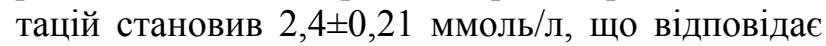
фізіологічним нормам. У первісток та нетелей на першому місяці тільності спостерігалася гіпер-

\section{БІБЛІОГРАФІЯ}

1. Звєрєва Г. В. Профілактика неплідності корів і телиць / Г. В. Звєрєва, О. І. Сергієнко, Б. М. Чухрій [та ін.]. // К. : Урожай, 1981. - 102 с.

2. Левченко В. I. Ветеринарна клінічна біохімія / В. І. Левченко, В. В. Влізло, І. П. Кондрахін. Біла Церква : БДАУ, 2002. - 400 с.

3. Медведева M. Клиническая ветеринарная лабораторная диагностика / М. Медведева. - М. : Аквариум, 2008. - 415 с.

4. Мороз И. Г., Литовченко Л. Н., Иваненко В. Г., глікемія, а у корів 3-4-ї лактацій рівень глюкози залишався на рівні верхньої фізіологічної межі. Під час п'ятого місяця тільності гіперглікемія спостерігалася в усіх трьох групах тварин. На сьомому місяці вагітності у нетелей та первісток ми виявили гіперглікемію, а у корів 3-4-ї лактацій рівень глюкози був на рівні верхньої фізіологічної межі; на восьмому та дев'ятому місяцях тільності рівень глюкози у них був високим порівняно з фізіологічними нормами. Гіперглікемія впродовж вагітності, ймовірно, була симптоматичною, обумовленою гіперфункцією надниркових залоз [6], у яких відбувається підвищена утилізація холестерину. Після родів і протягом перших двох тижнів післяродового періоду у корів показники рівня глюкози у сироватці крові знижувався до фізіологічної межі, що вказувало на зміну фізіологічного стану тварин - припинення вагітності, роди і післяродовий період.

Висновки: 1. Проведені біохімічні дослідження сироватки крові корів у динаміці показали, що впродовж усього перебігу вагітності у них спостерігалася гіперглікемія; лише у тварин 3-4-ї лактацій на першому та сьомому місяцях вагітності вміст глюкози в сироватці крові піддослідних тварин був на рівні верхньої фізіологічної межі.

2. Впродовж перших двох тижнів післяродового періоду вміст глюкози в сироватці крові корів усіх груп становив від 2,4 до 3,2 ммоль/л, що є фізіологічною нормою для даного виду тварин.

3. Підвищення вмісту глюкози в сироватці крові корів у період вагітності обумовлено, ймовірно, активуванням енергетичного обміну організму матері внаслідок інтенсивного росту й розвитку плода в даний період, а, можливо, й гіперфункцією надниркових залоз.

4. Встановлені в дослідах зміни вмісту глюкози в сироватці крові не були пов'язані 3 виникненням акушерсько-гінекологічних захворювань, оскільки роди в усіх піддослідних тварин проходили без ускладнень.

Санин А. Г., Гнедова Л. А. Профилактика бесплодия коров / И. Г. Мороз, Л. Н. Литовченко, В. Г. Иваненко [и др.] // Ветеринария. - №3. 1983. - С. 48-49.

5. Страйер Л. Биохимия.-М. : Мир.-Т. 2.-1985. -307 с. 6. Яблонський B. A. Ветеринарне акушерство, гінекологія та біотехнологія відтворення тварин 3 основами андрології / В.А. Яблонський, С. П. Хомин, Г. Л. Калиновський [та ін.]. - Вінниця : Нова книга, 2008. - 599 с. 